\title{
A study of the statutory background for worker cooperatives in the US: a proposal for a regulatory framework
}

(Estudio del marco jurídico de referencia para las cooperativas de trabajo asociado en los EE.UU.: una propuesta de regulación a nivel federal)

\author{
Sofía Arana Landín ${ }^{1}$ \\ University of the Basque Country (Spain)
}

Summary: 1 . Introduction. 2. The concept of worker cooperatives. 3. Workers' cooperatives in the USA, their tax regulation at a federal level: a view through judicial doctrine. 4. Statutory background. 4.1. The Single Tax principle. 4.1.1. The Mississippi Valley Portland Cement v. USA: the substance over form doctrine and a definition of patronage refunds. 4.2. The $50 \%$ rule. 5. The Statutes of incorporation at a State level. 6. A proposed model for unincorporated cooperatives: The Uniform Limited Cooperative Association Act. 7. Conclusions. 8. References.

Sumario: 1. Introducción. 2. El concepto de cooperativas de trabajo. 3. Las cooperativas de trabajadores en los Estados Unidos, su regulación fiscal a nivel federal: una visión a través de la doctrina judicial. 4. Antecedentes legales. 4.1. El principio del impuesto único. 4.1.1. Mississippi Valley Portland Cement v. EE.UU.: la sustancia sobre

1 Grupo de Investigación GIC 15/0 8 del Sistema Universitario Vasco, Universidad del País Vasco (UPV/ EHU), Visiting Scholar at the CUNY Graduate Center and the Murphy Institute, in New York. Email: sofia.arana@ehu.es.

I hereby thank Dr. John Mollenkopf for his kind invitation and support. I have to give very special thanks to Rebecca Lurie, at CUNY Murphy Institute, Director of the "Worker Ownership Project" who has been the main pillar of it all. Always with an incredible disposition she has introduced me to great people working on cooperativism, like Chris Adams, from the Legal Clinic at CUNY Law, Chris Michael, from ICA, Maggie Marron, at the Urban Justice Center or Carmen Huertas-Noble, Director of the Community and Economic Development Clinic, at CUNY Law School and so many others that I cannot name, but I thank them all. Special thanks to Tiffany Collins for her kind suggestions. I also want to thank the Public Advocate, Letitia James team and Birch Ha Pam for kindly listening to our ideas and looking for ways to put them into practice in New York City and devoting their time and effort to do so. 
la doctrina de la forma y una definición de reembolsos de patrocinio. 4.2. La regla del $50 \%$. 5. Los Estatutos de constitución a nivel estatal. 6 . Un modelo propuesto para cooperativas no constituidas en sociedad: la Ley de Asociación Cooperativa Limitada. 7. Conclusiones. 8. Referencias.

Abstract: The lack of a clear and comprehensive regulatory framework for worker cooperatives is one of the main causes for their scarcity in the USA, as it causes ignorance and uncertainty even though cooperatives are one of several forms of doing business recognized by the Internal Revenue Code (like sole proprietorships, partnerships, limited liability companies, LLC's, and Subchapter $\mathrm{S}$ corporations). Tax laws divide businesses into those categories, each with its own special tax provisions and worker cooperatives try to fit into any of those forms of business while "acting on a cooperative basis", thus, having their own specificities.

Even though at a State level there are regulations for agricultural cooperatives in all States, there are only less than 30 States that have either worker cooperative regulations, general cooperative regulations or consumer regulations which worker cooperatives can use.

However, the situation in the USA now demands for these entities. The fact that a particular attention is being given to worker cooperatives as an aftermath of the recent crisis is not news, as we have seen, historically², cooperatives have traditionally emerged in situations where the public sector was unable to provide the response required by the people, for instance in support for

2 Although cooperation as a form of individual and societal behavior can be considered to be intrinsic to every human organization, the history of modern cooperativism can find its roots in the agricultural and industrial revolutions.

These roots can be traced to multiple influences. However, one of the most important ones can be found in the United Kingdom in the nineteenth century. A rejection of the so called "Poor Laws" in 1834 gave way to Friendly Societies which can be said to share common values with cooperatives. At the time, as certain institutions began to routinely distinguish between the 'deserving' and 'undeserving' poor, a movement of Friendly Societies grew throughout Britain based on the principle of mutuality, committed to self-help in the welfare of working people. Friendly Societies established forums through which the philosophy of one-member, one-vote was practiced in organization decision-making. The principles challenged the idea that every person should be an owner of property.

Throughout the second half of the nineteenth century there was a dramatic increase in the number of cooperatives. Friendly Societies and consumer cooperatives became the dominant form of organization amongst working people in industrial societies. From the mid-nineteenth century, mutual organizations also shared these ideas in economic enterprises, educational institutes, financial institutions and industrial enterprises. Their common aim was the principle that an enterprise or association should be owned and controlled by the people it served to, and share any surpluses on the basis of each members' cooperative contribution rather than their financial investment. 
financial access, housing, or decent livelihoods. As ZEULI and CROPP 3 state it: "The historical development of cooperative businesses cannot be disconnected from the social and economic forces that shaped them. Co-ops then, as now, were created in times and places of economic stress and social upheaval".

Different studies ${ }^{4}$ during the previous recession show how worker cooperatives increase their turnover and number of jobs, while other enterprises shrink, being this the reason why their study at this moment becomes a must.

Thus, there should be a minimum understanding and control of what a worker cooperative is in order to be able to register and act like a real worker cooperative. Quoting GUTNECHT5 "allowing something that is not a cooperative to call itself a cooperative squanders a precious asset - the goodwill and public trust that reposes in the word 'cooperative'".

Thus, the USA is missing a very important instrument in order to fight against unemployment, inequality, income maldistribution and unsustainable development at a time when there is a conscience by a majority of the population in different movements that demand a change. This change is possible if educational, cultural and legal issues are properly addressed, as it has been done in other countries and higher instances ${ }^{6}$, creating a fairer, equitable and more cohesive and sustainable society, thus a better world to live in.

This paper aims to conduct a comparative statutory research on cooperative law for worker cooperatives in the USA, with a view of promoting an increased understanding within the academic and governmental communities, at a national and international level in order to promote worker cooperatives. In the case of New York public policies tacking this issue are already being devised. If this goal is achieved we will all benefit from them.

Keywords: worker cooperatives, taxation, USA, IRC, judicial doctrine

Resumen: La falta de un marco regulatorio claro y completo para las cooperativas de trabajadores es una de las principales causas de su escasez en los Estados Unidos, ya que provoca ignorancia e incertidumbre, aunque las cooperativas son una de las varias formas de hacer negocios reconocidas por el Código de Ingresos Internos (como empresas unipersonales, sociedades, compañías de responsabilidad limitada, LLC y corporaciones del subcapítulo S). Las leyes fiscales dividen a las empresas en esas categorías, cada una con sus propias disposiciones fiscales especiales y las cooperativas de trabajadores tratan

3 ZEULI, K.A. and CROPP, R., (2004), Cooperatives: principles and practices in the 21st century, Uw extension. Madison, p.9.

4 For instance, Salvatori's study in the case of Italy "Cooperatives provide an alternative model for the future of work", before the ILO April, the $6^{\text {th }} 2017$. 2011.

5 GUTKNECHT, Dave, "More on New Co-op laws", Endcap articles, March 24,

6 For instance, in Europe a European Cooperative Society was adopted by Regulation No 1435/2003 on the Statute for a European Cooperative Society (SCE) in order to help cooperatives act transnationally and grow. 
de encajar en cualquiera de esas formas de negocios mientras «actúan sobre una base cooperativa», por lo tanto, tienen sus propias especificidades.

A pesar de que a nivel estatal existen regulaciones para las cooperativas agrícolas en todos los estados, solo hay menos de 30 estados que tienen regulaciones sobre cooperativas de trabajadores, regulaciones generales sobre cooperativas o regulaciones de consumo que las cooperativas de trabajadores pueden usar.

Sin embargo, la situación en los EE.UU. ahora exige una respuesta para estas entidades. El hecho de que se preste especial atención a las cooperativas de trabajadores como consecuencia de la reciente crisis no es una noticia; como hemos visto, históricamente, las cooperativas han surgido tradicionalmente en situaciones en las que el sector público no pudo proporcionar la respuesta requerida por la gente, por ejemplo, en apoyo al acceso financiero, vivienda o medios de vida decentes. Como ZEULI y CROPP afirman: «El desarrollo histórico de las empresas cooperativas no puede desconectarse de las fuerzas sociales y económicas que las conformaron. Las cooperativas entonces, como ahora, fueron creadas en tiempos y lugares de estrés económico y agitación social».

Los diferentes estudios realizados durante la recesión anterior muestran cómo las cooperativas de trabajadores aumentan su volumen de negocios y el número de empleos, mientras que otras empresas se reducen, por lo que su estudio en este momento se convierte en una necesidad.

Por lo tanto, debe haber un mínimo de comprensión y control de lo que es una cooperativa de trabajadores para poder registrarse y actuar como una verdadera cooperativa de trabajadores. Al citar a GUTNECHT «permitir que algo que no es una cooperativa se llame a sí mismo una cooperativa despilfarra un bien precioso - la buena voluntad y la confianza pública que se encuentran en la palabra "cooperativa"—».

Por lo tanto, a los Estados Unidos les falta un instrumento muy importante para luchar contra el desempleo, la desigualdad, la mala distribución de los ingresos y el desarrollo insostenible en un momento en que la mayoría de la población tiene conciencia en diferentes movimientos que exigen un cambio. Este cambio es posible si las cuestiones educativas, culturales y legales se abordan adecuadamente, como se ha hecho en otros países y en instancias superiores, creando una sociedad más justa, equitativa y más cohesionada y sostenible, por lo tanto, un mundo mejor para vivir.

Este documento tiene como objetivo realizar una investigación jurídica comparada sobre el derecho cooperativo para cooperativas de trabajadores en los Estados Unidos, con el fin de promover una mayor comprensión dentro de las comunidades académicas y gubernamentales, a nivel nacional e internacional para promover las cooperativas de trabajadores. En el caso de Nueva York ya se están ideando las políticas públicas que abordan este tema. Si se logra este objetivo, todos nos beneficiaremos de ellas.

Palabras clave: cooperativas de trabajo asociado, tributación, EE.UU, Código tributario, doctrina judicial. 


\section{Introduction}

As Monique F.Lerroux says: "We need to develop a plural economy. A solid society is composed of three pillars: a democratic government, dynamic companies and in the middle, a very strong co-operative sector, combining business and people. It is about bridging the economy and the society".

Worker cooperatives have a very long tradition in some EU countries, particularly in the UK and Mediterranean countries such as Spain, Italy or Portugal. Moreover, in some of these countries the access of workers to capital is promoted from the highest possible source: their Constitutions $^{8}$.

In the USA cooperative principles have a very long tradition as their historical roots can be traced back to Benjamin Franklin who helped form what is considered the first formal cooperative business in the United States in 1752. It was a mutual fire insurance company ${ }^{9}$.

However, in the USA there is no such constitutional promotion, even though worker cooperatives can be said to be in the spirit of the US constitution, as the first time ever a tax public policy including benefits was adopted in this country was for a democratic profit sharing. In fact, the 1792 Bill for Cod fishers gave a bounty only if vessel owners distributed the profits with fishermen in a proportion of 3 parts for the owners and 5 parts to fishermen.

I find these roots remarkable, as the fact that income derived from the fishermen work and the owner's capital had to be distributed fairly, became so important that a Bill was passed for this purpose. We have to remember that at those times this Bill was considered by some to be doubtfully in the letter of the US Constitution but it fulfilled its spirit, even before the Constitution amendment in order to authorize Congress to adapt the meaning of the General Welfare clause.

With the amendment of Philadelphia these sort of public policies can be taken and are in fact being taken, most particularly for ESOPs. Thus, there is no constitutional obstacle for it.

7 LERROUX, M., F., president of the International Cooperative Alliance at the International Seminar on Co-operatives and the Sustainable Development Goals (SDG's) held in Brazil, 03-22-2017.

8 In the case of Spain art.129.2 of the Constitution says that access to capital from workers, as in cooperatives is to be promoted.

9 INGALSAVE, G. and GROVES, F. (1989), Historical Development, in Cooperatives in agriculture, 106 at 110-11. 
However, even though there is no longer such an obstacle we cannot find that too many tax policies have been adopted at a federal level and the ones that have been adopted they may not be the most adequate ones for the real promotion of worker cooperatives.

However, the law of cooperatives already benefits from internationally recognized cooperative principles that have existed, in various forms, for over a century that can set the pillar in which to sustain a possible new framework for US worker cooperatives. Only if a regulatory framework is based in them should cooperatives be called so.

\section{The concept of worker cooperatives}

First of all, we need to give a definition for the concept of "cooperative". A possible one is "an autonomous association of persons united voluntarily to meet their common economic, social and cultural needs and aspirations through a jointly-owned and democratically-controlled enterprise" 10 .

Up to this point both Europeans and Americans would agree on the definition. However, this definition does not include the whole list of values and principles that it comprises and their fulfillment and control may substantially vary. And here lies the main problem: in European countries there is usually a comprehensive regulation regarding the full commitment of cooperatives to their values by means of legal principles. These regulations may vary from country to country and they are usually stricter in the Mediterranean ones, where cooperatives are particularly important, but they all offer a framework for cooperatives to be constituted as such and public policies in order for them to be able to work and grow.

Cooperatives values and principles can be easily recognized as those that still remain today in cooperativism and were taken by the National Liaison Committee for Mutual, Cooperative and Associative Activities $^{11}$.

This set of co-operative values and principles designed in order to leave behind the excesses of the era were compiled by the Interna-

10 Definition by the International Co-operative Alliance (1995).

11 The primacy of the individual and the social objective over capital, voluntary and open membership, democratic control by membership, the combination of the interests of members and the general interest, solidarity and responsibility, autonomy, etc. 
tional Cooperative Alliance ${ }^{12}$ in 1937 and were later revised in 1966 and $1995^{13}$. This latter revision included not only an update of the 1937 principles, but also an identity statement and two sets of values: basic and ethical. They are widely accepted and can be summarised as follows:

Co-operatives are based on the values of self-help, self-responsibility, democracy, equality and solidarity and in the tradition of their founders, members believe in the ethical values of honesty, openness, social responsibility and caring for the others. These values are behind the principles:

Democracy. Every person has the right to have a say and influence all decisions that affect their lives. Thus in co-operatives control is shared.

Equality. Every person is worthwhile in his/her own right and has the right to have his/her life, dignity and abilities respected and valued equally.

Equity. Each person should be treated fairly and have access to all that is necessary to live a meaningful and productive life.

Self-help and responsibility. People are interdependent and benefit from joining their individual efforts with others to achieve their aspirations and improve their lives, as each of us is responsible for our own actions and the impact of those actions upon others and ourselves.

Solidarity. Shared, coordinated action between individuals and groups is the best way to create a society. Solidarity limits our individual freedom, only to the extent required by a real respect for the dignity of others being equal to our own.

In order to put into practice the afore-mentioned values a set of principles inspire cooperativism and these principles usually have a clear impact in cooperative regulations. They exist in order to help us organize how the co-operative operates and set standards by which we can assess our achievements and make decisions. The co-operative difference has to be based on the core principles rather than the values because other types of entities share similar values. There can be said to be three core principles: member ownership, control and benefit.

12 Also known as Rochdale's principles of co-operation (1937). The International Cooperative Alliance met in Rochdale, Manchester in order to write down their common principles. They took the principles of the post- industrial revolution used by Friendly Societies and Co-operatives compiled them and take down what they thought was the core of cooperatives. Thus, still nowadays they are still known by the place in which they met, the Rochdale's principles of cooperation.

13 See BIRCHALL, Johnston (2005), "Co-operative principles ten years on", ICA. 
Voluntary and open membership. Co-operatives are voluntary organizations, open to all persons satisfying certain non-discriminatory conditions and willing to participate. People satisfying those conditions may join in no matter their gender, religion, race, etc. A specific provision to prevent possible discriminations within the cooperatives is to be made in their regulation.

Democratic member control: It is usually known as the "One member, one vote" principle. Co-operatives are democratic organizations controlled by their members, who actively participate in setting their policies and making decisions. It is not like the capitalist undertaking where rights depend on the capital investment, in cooperatives all members have equal voting rights.

Member economic participation. Benefits are distributed proportionally according to each member's level of participation in the cooperative, for instance by good salaries for all workers or by returns on sales or purchases, rather than according to capital invested.

In worker cooperatives this means that the differences in salaries from the lowest earning worker to the highest earning one cannot surpass a certain amount. In Mondragón MCC this ratio is of 4.5, even though the law permits it to be 1:9. Do we know how much this ratio is in a country where 400 people own more wealth than the bottom $61 \%$ or 194.000 .000 people $^{14}$ ?

Autonomy and Independence. They are self-help organizations controlled by their members. Whenever they make agreements with other organizations or raise capital from operations with non-members they keep their democratic control and maintain their autonomy.

Education and training. Members allocate surpluses for educational purposes $^{15}$.

Cooperation among cooperatives. Cooperatives serve their members most effectively and join the cooperative movement by working together through local, national, regional and international structures ${ }^{16}$.

Concern for the community. While focusing on members' needs, co-operatives work for the sustainable development of their commu-

14 Figures taken from ALPEROVITZ, Gar. (2017), Principles..p. 16.

15 In the case of Mondragón MCC, the leading worker cooperative in the world, they have to comply by the Basque Act on Cooperatives with a Compulsory Educational Fund, which is of a $10 \%$ of the yearly net surplus. This Fund goes to education, solidarity, projects for the environment or the community.

16 The inter-solidarity principle in cases like Mondragón Cooperative Group is seen in the fact that it comprises 120 cooperatives that help each other not only with cash needs, but also with the transfer of workers, technology and innovation. 
nities through policies accepted by their members. Thus, members can decide where to dedicate the Education and Promotion Funds and they usually reserve an important part for community projects.

If we had to sum it up, we would say that co-operatives are people centered rather than capital centered ${ }^{17}$. This is a unique feature that can justify a unique approach to certain aspects of income taxation.

Only if their regulation includes these principles they will not only be constituted as worker cooperatives but keep on being that for the benefit of the community and their own benefit.

However, as we can see, these principles make worker cooperatives constrained to them in order to stay true to their principles. Their returns cannot be compared to the possible dividends capitalist corporations distribute among owners because in order to comply with the principles an important part of the net surplus has to stay in the cooperative and the community.

This is one of the reasons why these funds can be regarded as taxes. The real spirit of any tax is to get resources for community, thus, general interest needs, and that is what cooperatives do. So, among these public policies for cooperatives a different taxation that bears it in mind can be said to be the basis.

Cooperatives do not act like normal corporations, for this reason they have their adapted taxation, which cannot be considered to be a benefit, but an understanding of their differences. I find it important to have a common definition of what worker cooperatives are in order to be able to make them visible and promote them through reasonable tax policies.

\section{Workers' cooperatives in the USA, their tax regulation at a federal level: a view through judicial doctrine}

Curiously enough, in the USA we cannot find evidence of all the afore-seen principles as written law for Company Law as cooperatives do not exist as a clear and separate legal entity following the mentioned principles, as in the case of EU countries.

What is more, the existing traditional entrepreneurial types may be ill-suited for the cooperative form of business. Thus, any sort of entity "operating on a cooperative basis" can consider itself to be a "coop"

17 As stated by J. Birchall (2010) in People-centred businesses: Co-operatives, Mutuals and the idea of Membership, p. 6. 
and has to try to cope with this particular system, without a proper comprehensive regulation at a federal level. This fact poses a problem of uncertainty and lack of recognition that should be tackled. Entities do not get along with uncertainty and so the number of worker cooperatives in the USA is scarce. This problem is probably enhanced by a very strong capitalistic culture. Thus, a proper and clear legal framework and public awareness and understanding in the matter are a must.

So, in the USA there is no simple and all-encompassing definition to distinguish an organization called a "cooperative" from other forms of business enterprise. As Justice Louis Brandeis ${ }^{18}$ once noted, "No one plan of organization is to be labeled as truly cooperative to the exclusion of others."

We can see that with the ERISA Act (1974) in order to legislate about another kind of workers access to capital, a clear legislative framework together with a generous taxation has had the desired effect of making ESOPs boom all over the country, benefiting employees and employers and above all, society, as these structures have also proved to be more resilient than normal corporations during the crisis. The effect has been a less loss of jobs during recessions. As KURTULUS and KRUSE ${ }^{19}$ state there are four broad sources of interest in employee ownership: increased economic performance, greater job security and firm survival, more broadly shared prosperity and lower labor-management conflict and higher quality of work life.

Even though there are three federal laws for cooperatives (the Capper Volster Act, the Agricultural Marketing Act of 1929, and the Farm Credit Act of 1971), all three of them are for agricultural and farmers cooperatives only. Thus, worker cooperatives do not have their own substantive regulation at this level.

It is really through judicial doctrine that we can find some answers to what a cooperative is. The Tax Court, in Puget Sound Plywood v. Commissioner20, (even though it was a case mainly directed to ascertain the possible application of section 501 of the Internal Revenue Code), described a cooperative as comprised of members who sought "(1) [f]or themselves to own and manage the [organization], as distinguished from having it owned and managed by outside equity inves-

18 Dissenting opinion in Frost v. Corporation Commission, 278 U.S. 515, 546 (1929), quoted in Ford-Iroquois FS, Inc. v. Commissioner, 74 T.C. 1213, 1217, n.3 (1980).

19 F.A. KURTULUS and D.L KRUSE (2017), How Did Employee Ownership Firms Weather the Last Two Recessions?: Employee Ownership Stability and Firm Survival:1999-2011, pp.1-2.

2044 T.C. 305, 307-308 (1965), acq. 1966-1 C.B. 3. 
tors; and then (2) to have their [organization] turn back to the members the excess of the receipts from the store sales over the cost of the goods sold and the expenses of operation."

This description identifies three basic principles or requirements for cooperatives, thus, it helps us identify the principles for worker cooperatives in the USA too:

(1) democratic control by the members (a cooperative satisfies this by periodically holding democratically conducted meetings, with members, each with one vote, electing officers to operate the organization);

(2) vesting in and allocating among the members all excess operating revenues over the expenses incurred to generate the revenues (i.e. operating at cost); and

(3) subordination of capital, as they are oriented to member patrons.

If we bear in mind that the principles sustaining the promotion of ESOPS are, at least, the same ones as the ones for worker cooperatives, we just cannot see a reason why worker cooperatives should not have the same level of protection, starting from a clear regulatory framework and an advantageous taxation adapted to them. Although they do have this adapted taxation, as we will see, maybe the existing measures could be considered to be ill-suited.

\section{Statutory background}

Several sources contribute to cooperative law. Curiously enough, in the end, we have to extract the meaning of what a cooperative is from taxation, as at a federal level there is no other regulation. Moreover, the Internal Revenue Code has to be complemented with the Internal Revenue Service rulings and above all, judicial doctrine. However, as we will see, most of the regulations were usually intended for agricultural cooperatives and not to worker cooperatives ${ }^{21}$, so they sometimes may be ill-suited for these last ones.

21 From NESS, Manning: The Sherman Act in 1890, while containing no specific language on cooperatives, was used by government officials to ban them. As agriculture cooperatives could set a common price, they were accused of practices against competition. The Clayton Act of 1914 sanctioned cooperatives by exempting all "agricultural, or horticultural organizations, instituted for the purposes of mutual help, and not having capital stock or conducted for a profit," from the Sherman Act. While the 
Thus, the Internal Revenue Code provides the legislative foundation for cooperatives, as it is not the type of entity to be found elsewhere. In a sense, the concept of cooperative has to be interpreted through the Tax Code, which contains provisions applicable to all businesses, and other language specifically referring to cooperatives, although not to worker cooperatives in particular.

The Internal Revenue Service, through a variety of administrative determinations, interprets the Tax Code and applies it to the situation of each taxpayer. We can find IRS rulings that give their opinion on the interpretation of different aspects of the Tax Code and that have already done so providing useful guidance for cooperatives.

However, we cannot consider these rulings as true sources of law, they can guide us, but it is for the courts of law to interpret the Code and act as final arbiter for any unsettled disputes between the Service and taxpayers over its meaning. We cannot forget that these rulings are just the Internal Revenue Service interpretation or opinion of the Tax Code and these rulings have sometimes proved to be wrong by the judicial doctrine ${ }^{22}$.

Several references to cooperatives can be found in the Internal Revenue Code, dating back for over a century. However, we cannot find in the IRC any new policies taken during the last decades and now it would be a great time to do so.

At the very beginning, different Acts were passed at a federal level to regulate cooperatives. However, they were specifically restricted to agricultural and farmer cooperatives. It was in 1936, during the Great Depression, that the Administration started regulating other sort of cooperatives like the electricity ones.

Clayton Act legalized non-profit cooperatives that issued no stock, the legal status of other cooperatives remained ambiguous until the 1920s. In 1922, US Congress passed the Capper-Volstead Act, commonly referred to as the "Cooperative Bill of Rights," allowing farmers to market products without violating antitrust laws. "However, under the new law cooperative members were required to engage in agricultural production and all cooperatives had to follow a one-member-one-vote rule and annual dividends on stock or capital could not exceed eight percent. In addition, non-member business could not exceed 50 percent of the cooperatives total business. A decade later, in 1933, the US Congress extended the rights of cooperatives through passage of the Farm Credit Act that created a network of cooperative lending institutions to provide loans for agriculture and farmers' cooperatives".

22 As it was the case of revenue ruling 61-47, 1961-1 C.B. 193, holding that amounts distributed by a workers' cooperative association to its members on the basis of man-hours worked are not true patronage dividends eligible for deduction at the cooperative level and the case of the so called "50\% rule" in Revenue Ruling 93-21, 1993-1 C.B. 188. 
In the War Revenue Act (1898) Congress recognized the contributions and importance of cooperatives. Congress provided exemption from federal excise taxes to cooperative companies, not-for profit mutual benefit associations, and agricultural or horticultural, among others.

This long history tells us that cooperatives can be regulated at a federal level, not only by what could be inferred from the Internal Revenue Code, but as entities to be regulated and promoted as there have been different attempts that have done so regarding agricultural, farmers, electricity, and other sorts of cooperatives.

However, the only legal framework at a federal level to be found today for worker cooperatives is in the IRC.

Revenue Act 1916 (IRC 1916) made a clear distinction of the cooperative regime for farmers' cooperatives regulating it on its own, in section 521, mutual or cooperative insurance companies, ditch or irrigation companies, telephone companies and "like organizations", regulating them in section 501.c (12) and all other cooperatives, those of subchapter $T$, where worker cooperatives can be assigned.

In 1951, Congress passed legislation which, when complemented by Treasury rulings, was thought to ensure that earnings of cooperatives, to the extent they reflected business activity, would be taxable either to the cooperatives or to the patrons, depending on their legal form. However, certain court decisions (Long Poultry Farms v. Commissioner, 249 F. 2 d 726 (4th Cir. 1957); Commissioner v. B. A. Carpenter, 219 F. $2 d 635$ (5th Cir. 1955)) held that non-cash allocations of patronage dividends generally were not taxable to the patron although the allocations were deductible by the cooperatives. Congress determined that further clarification was necessary.

In 1961, revenue ruling 61-47, 1961-1 C.B. 193, was issued holding that amounts distributed by a workers' cooperative association to its members on the basis of man-hours worked are not true patronage dividends eligible for deduction at the cooperative level.

The Service said this holds true even when a State law provides that work performed as a member of a workers cooperative is deemed to be patronage of the cooperative. It concluded that to be deductible as a true patronage dividend, the return had to be "...either an additional consideration due to the patron for goods sold through the association or a reduction in the purchase price of supplies and equipment purchased by the patron through the association." However, Senator Kerr disagreed with this, as he was of the opinion that worker cooperatives were the true form of cooperatives and should exclude patronage refunds, thus designing subchapter $\mathrm{T}$, in the way it lasts till today. 
This way, in 1962, Congress added subchapter T to the Code (consisting of IRC sections 1381 through 1388) to address the defects of prior law. It clarifies, in general, that:

a) A cooperative may exclude, as patronage refunds, amounts allocated in cash or scrip; and

b) Its patrons are currently taxed on such refunds.

In spite of this clarification, the IRS pursued its objective in litigation, as they did not want worker cooperatives to benefit from subchapter T. However, in Linnton Plywood Ass'n v. United States, 236 F. Supp. 227 (D.C. Ore. 1964) the judge gave his opinion contrary to that of the IRS.

Occasionally, when one aims to clarify matters we can make them more complicated, as it is the case. There is an important misuse of cooperative terminology, now even by Congress.

- By this clarification Congress commits several errors: first, because we cannot really speak of a "deduction", but, in purity, of an exclusion as patronage refunds are not computable as taxable income;

- second, because patronage dividends should not exist, as the outcome of patronage should be a refund and the word dividends is repeated;

- third, because it poses the problem of who can be considered to be a patron, as the IRC does not give a definition of what a patron is. Can members be considered to be patrons? And non members? However, Treasury Regulation § 1.1388-1(e) describes a patron as "any person with or for whom the cooperative association does business on a cooperative basis, whether a member or a nonmember of the cooperative association....". This way both members and non members can act as patrons.

In 1965, in the Puget Sound Plywood case the U.S. Tax Court issued a more thorough opinion on essentially the same facts, which referred to the "operating on a cooperative basis" language in Code sec.1381(a)(2), and reached the same conclusion, that worker cooperatives could exclude their patronage refund allocations. This case has not been overruled, so it is clear that the exclusion of patronage refunds when computing a worker cooperative income lasts still today. This rule can be known as the Single Tax Principle.

Therefore, the Code says that "any corporation operating on a cooperative basis" may receive the tax benefits of subchapter T. The Code does not include any specific definition of "operating on a coop- 
erative basis". The regulations repeat the Code language and add the phrase "and allocating amounts to patrons on the basis of the business done with or for such patrons."

As we can see, this lack of a regulatory definition does not mean that any entity, being or not a corporation can be said to act in a cooperative basis and use the provisions stated in the IRC for its taxation without further proof. Even though there is no clear regulation, judicial doctrine can give some light in the matter. In this sense, some guidelines can be found of what "acting on a cooperative basis" means through history and judicial doctrine.

\subsection{The Single Tax principle}

Cooperatives calculate taxable income like other corporations, but with one main difference based on the distinct way of distributing net margins to its patrons based on use, rather than to investors based on investment.

What cooperatives get is not profits, but income or margins and thus, we can speak of net income, net margins or a net surplus.

A good use of this terminology is important in order to establish the differences with traditional corporations.

This difference is the basis for the Single Tax Principle that applies when business income sources and distribution methods can be considered to be "cooperative" in nature. Earnings from sources other than patronage and margins not distributed in the manner specified by the Code are generally not eligible for single tax treatment.

As the sharing of profits within worker cooperatives is very different from that of a traditional enterprise and being as there no written rules of what that means in the USA, we can find through judicial doctrine this important legal characteristic.

Income distribution in workers cooperatives consists of two elements: the distribution based on the work accomplished by each worker and the creation of 'reserves' which contribute to the consolidation of the firm's financial standing. This profit sharing model explicitly recognizes the value of employee labor and the importance of making the firm sustainable so that it may be handed over to future generations. However, this second part, cannot be found in the USA system and, as we will see, the lack of it weakens worker cooperatives making them extremely vulnerable.

The general principle of cooperative income taxation is that money flows through the cooperative and on to patrons, leaving no margins 
to be retained as profit by the cooperative. Thus margins are taxed only once. The tax is ultimately paid by the final recipient (the cooperative patron), although under some circumstances the cooperative pays tax on a temporary basis, then receives a deduction when the money is finally passed on to the patron. The way to do this is by the exemption of patronage refunds.

This constitutes the underlying principle for the exclusion of patronage refunds from taxable income. This practice was already settled a century ago as a 1918 ruling makes the following observation: "the deduction of patronage dividends was a settled practice in the administration of the income-tax laws".

As previously mentioned, Subchapter T cooperatives are governed by I.R.C. sections 1381-1388, which are devoted to cooperatives conducting any kind of business, not being exempt from federal income tax. Depending on their actual legal form, their earnings are taxed at either the cooperative or member-patron level. Thus, if they adopt the form of $C$ Corps the cooperative itself is going to be the taxpayer, whilst if the adopted form is that of an S Corp they can be pass- through, being the members the taxpayers. If they are an LLC they could generally choose to be taxed as corporations or to be passthrough.

The main difference between cooperatives and other corporations is that because of the Single Tax principle they do not incur in double taxation out of patronage source earnings, being taxed only once. Therefore, they can exclude the patronage-source earnings they distribute to its member-patrons from their gross income. Only patronagesource earnings are eligible for exclusion by the cooperative and the conditions for this tax treatment include an agreement by the patron to recognize the full patronage refund for tax purposes even though it is not received in cash or negotiable form (as allocated income).

So one of the main differences in taxation when compared to other sorts of entities is precisely the exclusion from income tax at a corporate level of patronage sourced income when distributed under certain conditions (in cash or what can be considered to be a qualified method of payment), which is only going to pay taxes at a taxpayer level.

However, a subchapter T cooperative must usually pay tax on the patronage source earnings it retains. Thus, when cooperatives have income that they want to keep in order to fortify the cooperative funds, no consideration is given to reserves and they have to pay just as any traditional corporation. This way, the single tax treatment is lost. If the funds are later distributed, the recipients must pay a second income tax at the recipient level. 
I find that was has been designed as an incentive for cooperatives can become an important disincentive for their resiliency, as it is the money sent to reserves what makes a cooperative strong and resilient in the long run. If cooperatives are going to be different from other types of corporations they have to look after the cooperatives financial health avoiding their decapitalization. The patronage refund clause looks at enhancing the distribution of refunds back to patrons, penalizing their non distribution. Moreover, this clause can be said to be contrary to the ones we find in most of the very developed countries in relation to cooperatives, where the allocation of margins to reserves is usually compulsory and promoted by law, partly or totally excluding them from taxable income.

The way the US legislator saw it the margins had to pay income once, so if it is refunded to patrons it is excluded from taxation at the cooperative. However, if it stays in the cooperative patrons do not receive their share but the cooperative has to pay for those margins as they can no longer be considered to be distributed patronage refunds. If later, part of those reserves go back to patrons they will pay income tax again. As an example in Cooperative Oil Ass'n v. Commissioner, 115 F.2d 666 (9th Cir. 1941), the exclusion of patronage refunds was not permitted where some net margins were not allocated or distributed to patrons but were placed instead in a working capital reserve.

Measures in the IRC in order to promote the cooperative funds can be considered to be a must. So a good incentive would be the exclusion (or a reduced inclusion) from taxable income of margins devoted to reserves. In the end, if these reserves were not used for the cooperative and instead they were distributed to members they would then pay income tax. In this case it would just be a deferral of taxes that could greatly help the allocation of inner resources to these funds making cooperatives undeniably more resilient. If the cooperative ended up not distributing the reserve it would be for the benefit of the cooperative in the long run. This way it would become stronger and resilient. In this case, a partial exclusion of the percentage compulsorily devoted to reserves could be in accordance with what is done in other countries with strong cooperatives.

Last, worker cooperatives cannot qualify to use section 521, as it is devoted to farmers' cooperatives or section 501(c)(12) as it provides federal income tax exemption for benevolent life ,insurance associations of a purely local character, mutual ditch or irrigation companies, mutual or cooperative telephone companies, electric companies, or "like organizations". 


\subsubsection{The Mississippi Valley Portland Cement v. USA: the substance over FORM DOCTRINE AND A DEFINITION OF PATRONAGE REFUNDS}

The Mississippi Valley Portland Cement v. USA case ${ }^{23}$ is a clear precedent of the use of the substance over form doctrine and the true economic reality test as effective methods of unmasking pretended entities "working on a cooperative basis".

In this case, the taxpayer, a said to be nontax-exempt co-operative incorporated in Mississippi, sought to deduct distributions to its shareholders from its corporate income tax as "patronage dividends." These payments were made from the corporation's net profits during the tax years in question. After excluding patronage dividends, the taxpayer reported no taxable income for several years.

The District Court went as follows: "There is nothing in the method of doing business by the taxpayer in this case that distinguishes it from the average or normal corporation doing business for profit, no matter that the taxpayer is called a cooperative, or that the dividends to stockholders are referred to as patronage rebates. Other characteristics of this taxpayer, akin to that of a corporation for profit is that the dividends were payable only to stockholders of record at the end of each fiscal year, leaving stockholders, who might have sold their shares prior thereto, with no entitlement to a rebate on the basis of earnings during the fiscal year; and the fact that, as stipulated, actually no stockholder used the cement produced. All allocations were assigned to a sales agency or sold by that agency. As further stipulated, any allocations and delivery of cement to a patron were discouraged."

"It is the opinion of this Court, after carefully scrutinizing the structure of this taxpayer and its method of doing business, that it was not doing business with its consumer patrons or assigns in the historical sense of a consumer cooperative, but that its stockholders are in no different category from that of any corporation interested in profits, no matter whether the source of that profit be from the production of cement or any other product, and that accordingly the sums paid here are not excludable from taxable income."

So, in this case, the Court decided that the taxpayers distribution of its net profits could not be categorized as patronage dividends in the sense of Section 1388(a), as added by the Revenue Act of 1962, which provides as follows:

23408 F.2d 827 (1969), n. 2561 US Court of Appeals Fifth Circuit.March 14, 1969. 
"(a) Patronage Dividend. - For purposes of this subchapter, the term 'patronage dividend' means an amount paid to a patron by an organization to which part I of this subchapter applies -

(1) on the basis of quantity or value of business done with or for such patron.(2) under an obligation of such organization to pay such amount, which obligation existed before the organization received the amount so paid, and(3) which is determined by reference to the net earnings of the organization from business done with or for its patrons.

Such term does not include any amount paid to a patron to the extent that (A) such amount is out of earnings other than from business done with or for patrons, or (B) such amount is out of earnings from business done with or for other patrons to whom no amounts are paid, or to whom smaller amounts are paid, with respect to substantially identical transactions."

Of particular importance to the disposition of this case is the language requiring that the distribution be made out of earnings from "business done with or for patrons". On the one hand, the Commissioner argues that "with or for" mean that the patrons must physically handle the products of the cooperative. On the other hand, the taxpayer argues that neither the statute nor the cases have imposed such a physical contact requirement. In previous cases evidence that the patron actually used the product points logically to the conclusion that the business was conducted "with or for" such patron. Conversely, the absence of such evidence would support, but not compel, a conclusion to the contrary.

However, the district court, 280 F. Supp. 393, agreeing with the Commissioner, said that notwithstanding the "cooperative camouflage", these payments were in reality no more than dividends paid to the corporation's shareholders, as the taxpayer's method of conducting his business was not distinguishable from normal corporations doing business for profit. Moreover, the so called "patrons", were just "paper patrons" as they had no actual contact with the cement. Thus, lifting the veil the economic reality was unmasked and it was held that patronage dividends were not deductible.

Notwithstanding, as we have said, the language is not too precise, again, as there seems to be two errors:

- first, we cannot really speak of a deduction, but of an exemption which is easier to prove than deductions, which belong to legislative grace. The so called "patronage dividends" should be excluded at the time of computing income not taken into account and later deducted; 
— second, it is also imprecise to refer to "patronage dividends" as we are speaking of "patronage refunds". The legal nature of dividends from capitalistic entities and refunds from cooperatives is not exactly the same.

Earnings on non-cooperative operations, like those of investor-general corporations, are subject to taxation at both the firm and ownership levels. So, this way, the exclusion of the patronage refund is obviously only for cooperative operations and for all other operations the general regime applies.

Another factor that has been used by the IRS for determining what working on a cooperative basis means is the so called " $50 \%$ rule", that will be explained now. However, it should be noted that this rule is no longer applicable to worker cooperatives for the Internal Revenue Code purposes.

\subsection{The $50 \%$ rule}

In general, worker cooperatives can be said to be cooperatives which are primarily owned by their employees as employees hold a majority of capital and voting rights.

This fact is in their nature, as if they were not primarily owned by employees or employees did not have an important amount of voting rights, they would not be worker cooperatives, even if they chose the name.

Within the uncertain US system we cannot find the above mentioned fact as written law in the Internal Revenue Code for worker cooperatives, though we can find it for agricultural and farmers cooperatives. The Internal Revenue Service changed its interpretation of whether "operating on a cooperative basis" required more than 50 percent of the cooperative's business to be done with members on a patronage basis to qualify for tax treatment in Revenue Ruling 93-21, 1993-1 C.B. 188, it is stated that the 50 percent threshold is not necessary.

The US Supreme Tax Court decided that the 50\% requisite was not applicable to worker cooperatives, as it is in a section not applicable to them (farmer cooperatives). This is the reason why the IRS had to change its interpretation and no longer asks for this $50 \%$ minimum of business done with members on a patronage basis to qualify for the cooperatives tax treatment. In my opinion, the US Court of law decided what should be decided according to the law, as it is true that the $50 \%$ minimum is in another section of the IRC. However, it is the 
law that should reasonably be changed in order to ask for this minimum. Otherwise, in the end, the real nature of cooperatives is lost on the way. All cooperatives need to bear in mind the cooperative principles and the principle of mutuality is a pillar for them. Not asking for a minimum gives a chance for other sorts of traditional corporations to pretend to act on a cooperative basis for some of their members, when the vast majority of the business can derive from operations with non members. Bearing in mind that in the end, even though they act on a cooperative basis they are traditional types of business, this can surely happen very often.

Moreover, for other purposes there can be a need to comply with this $50 \%$ rule. This could be the case of the Statutes of incorporation at a State level, as incorporation offers advantages over other forms of doing business where a large number of persons may become involved in the venture, facilitating also succession ownership. Incorporation is also important as it limits the personal liability of each member, for losses suffered by the cooperative, to the members' equity in the cooperative and this $50 \%$ rule may be applicable in different States.

Even more, the recent bill proposal ${ }^{24}$ by Sanders, Gillibrand, Leahy and Hassan to provide for the establishment of the United States Employee Ownership Bank, and for other purposes is based on section 1082 where a $51 \%$ worker ownership is required, the same applies to 1042 (c) 2 of the IRC in order to receive the tax benefits applicable for the transfer of a business. These facts should be born in mind.

\section{The Statutes of incorporation at a State level}

In the USA, corporations are chartered by state law, not federal law, so there are fifty state corporate statutes. The cooperative by-laws could be used in a business corporation in any of the states. However, the fact that different forms of corporations can act as "coops" make matters difficult because it becomes a hard task to determine whether these entities act like true cooperatives or not.

Thus, cooperative tax treatment is available to any organization that comes within the scope of "operating on a cooperative basis" under the Internal Revenue Code. However, there are non-tax statutes that establish cooperative characteristics which are taken into account because taxation is only one external factor.

24 . May $10^{\text {th }} 2017$,

Boletín de la Asociación Internacional de Derecho Cooperativo

ISSN: 1134-993X • ISSN-e: 2386-4893, No. 54/2019, Bilbao, págs. 19-54

doi: http://dx.doi.org/10.18543/baidc-54-2019pp19-54 • http://www.baidc.deusto.es 
All States have recognized cooperatives' unique characteristics by enacting statutes specifically designed for incorporating cooperatives. However, even though the 50 States have Statutes of incorporation, most of them are devoted to agricultural cooperatives. Thus, not all States have statutes that can be used by worker cooperatives.

In most of the States where worker cooperatives can incorporate, the Statutes of incorporation are general cooperative Statutes and only some of them are worker cooperative specific statutes. In some others, there are consumer cooperative statutes that worker cooperatives can also use ${ }^{25}$. The last State to have approved worker cooperative Statutes is the State of Rhode Island in March 24th 2017.

25 In the different States that have either a general cooperative Statute or a worker or consumer cooperative State worker cooperatives can use the legal information can be found in the following:

In Alaska, Alaska Cooperative Corporation Act Statutes (AS 10.15.005 - 10.15.600) https://www.commerce.alaska.gov/web/portals/5/pub/corporationsstatutesandregulations. pdf;

For Arkansas, Arkansas AR-AG: Ark. Code. Ann. § 4-30-101 - 4-30-118; California Cooperative Corporation Law §§ 12200 et seq.; http://www.leginfo.ca.gov/cgi-in/displaycode? section=corp\&group=12001-13000\&file=12200-12203;

For Colorado, in Colorado Cooperative Act, 7-56-101 7-56-901, C.R.S. (West 2016), http://www.lexisnexis.com/hottopics/Colorado/ , under Title 7, Article 56, Associations;

In Florida, FL-AG F.S.A. §s 618.01 to 618.28 ;

In Georgia GA-Ag. O.C.G.A. Sections 2-10-80 through 2-10-111;

In Illinois, the information can be found in 805 III. Comp. Stat. 310/1310/27; http:// www.ilga.gov/legislation/ilcs/ilcs3.asp? ActID=2295\&ChapterID=65;

In lowa, it can be found in lowa Code §499; https://www.legis.iowa.gov/DOCS/ACO/IC/ LINC/Chapter.499.pdf;

In Missouri, MO-Gen-1; Missouri Revised Statutes $\S \S 357.010$ to 357.190, http://www. moga.mo.gov/mostatutes/ChaptersIndex/chaptIndex357.html;

in Montana, Mont. Code Ann. (2015); §§ 35-15-101 to 35-15-507; Montana Cooperative Associations http://leg.mt.gov/bills/mca_toc/35_15.htm;

In New York, NY-CC: N.Y. C.C.O. Law § 1-101 et. Seq (Consol. 2015), New York Cooperative Corporations Law: http://codes.findlaw.com/ny/cooperative-corporations-law/\#!tid= ND66BA6417A1046DE84120ED30987B50B;

In Ohio, OH-Gen Sections 1729.01 to 1729.99 http://codes.ohio.gov/orc/172;

In Oregon, OR-Gen, Oregon Revised Statutes Title 7 Corporations and Partnerships Chapter 62 Cooperatives $\S \S 62.005$ to 62.992; http://www.oregonlaws.org/ors/chapter/62 ;

in South Dakota, SD-Gen; S.D. Codified Laws §§ 47-15-47-20 (West 2007); http://sdlegislature.gov/Statutes/Codified_Laws/DisplayStatute.aspx?Statute=47\&Type=Statutete;

In Virginia, VA-Gen: Va. Code Ann. § 13.1-301-13.1-311.1 (West 2016); http://law.lis. virginia.gov/vacode/title13.1/chapter3/;

In West Virginia, WV-Ag (and more) WV Code §19-4 http://www.legis.state.wv.us/Wvcode/ChapterEntire. $\mathrm{cfm}$ ?chap=19\&art=4;

In Wisconsin, WI-UA Coop Chapter 193: Wis. Stat. § 193.001-193-971; http://docs.legis.wisconsin.gov/statutes/statutes/193 and WI-Gen: Wis. Stat. Ann. § 185.97 (West 2016); http://docs.legis.wisconsin.gov/statutes/statutes/185.pdf. 
In all of them, these statutes create a corporate form that is owned and controlled by its members, and which operates for their benefit. However, Statutes vary in their specificity. In most of them General Corporate law applies as supplemental law. However, in Missouri General Corporate Law does not apply as stated in MO-Gen-1 § 357.010.

The names cooperatives adopt are not the same and in many cases, there is not even a reference to be "coop." in their nicknames. If an entity is truly a cooperative, then it should be clear that it is, by using either the word cooperative or the nickname "coop". The variety of nicknames does not really help identify them.

For instance in Arkansas the nickname they have is "AR-Gen" for Cooperative Associations Generally, in California "CA-Coop" for California Cooperative Corporation Law, in Colorado "CO-Gen" for Colorado Cooperative Act, in Florida "FL-AG" for Florida Cooperative Associations Generally, in Georgia "GA-Ag" for Georgia Cooperative Marketing Act, in Illinois "IL-Gen" for Illinois Cooperative Act, in lowa "IA-Gen" for lowa Cooperative Associations Generally, in Missouri "MO-Gen-1" for the Missouri Company Cooperatives Act, in Montana "MT-Assn" for Montana Cooperatives Association, in New York "NYCC" for New York Cooperative Corporations Law or "NY-BSC" for New York Business Corporation Law, in Ohio "OH-Gen" for Ohio Cooperative Law, in Oregon "OR-Gen" for Oregon's General Cooperative Statutes, in South Dakota "SD-Gen" for South Dakota Cooperatives Association Act, in Virginia "VA-Gen" for Virginia Cooperative Associations, in West Virginia "WV Coop" for West Virginia Cooperative Associations and in Wisconsin "WI-Gen" for Wisconsin Cooperative Act and "WI-UAcoop" for Wisconsin Unincorporated Cooperative Associations Act.

In all of the afore-mentioned States the articles of incorporation require the cooperative's name and the incorporator's signature but for Wisconsin Unincorporated Cooperative Association Act that does not specifically require this. In the case of New York BSC they can also be signed by an attorney, officer or director.

There are several definitions of what a cooperative under their Statutes of incorporation can be, although they are varied as we can see: in California, CA-COOP § 12201 states: "...(A) corporation may be formed under this part for any lawful purpose provided that it shall be organized and shall conduct its business primarily for the mutual benefit of its members as patrons of the corporation...(s)uch corporations are democratically controlled and are not organized to make a profit for themselves, as such, or for their members, as such, but primarily for their members as patrons"; in Colorado, CO-Gen 
§7-56-103(6) says when defining a Cooperative: " (a) The business is operated at cost by adjusting the prices charged for goods or services or by returning any net margins at the end of a fiscal year on a patronage basis to members and other persons qualified to share in the net margins; (b) Dividends on stock or interest on equity capital is limited, as prescribed in the articles or bylaws; (c) Voting rights limited to members of the cooperative as prescribed in the articles or bylaws; (d) The cooperative's business carried on for the mutual benefit of its members; and (e) Members not liable for any debt, obligation, or liability of the cooperative"; In lowa, IA-Gen $\$ 499.2$ defines a "cooperative association" as "one which deals with or functions for its members, which distributes its net earnings among its members in proportion to their dealings with it, and in which each voting member has only one vote"; In Montana it can be inferred from MOGen-1 § 357.010 to 357.190: § 357.090 that provides the following: "each shareholder has the right to cast only one vote regardless of number of shares held", and § 357.100 provides that "each shareholder has only one vote on issues to be decided directly by shareholders, regardless of number of shares held" in Wisconsin, WI-UA Coop § 193.005(9) says: "Cooperative" means "an association organized under this chapter conducting business on a cooperative plan as provided under this chapter".

Even the nature of the cooperative varies as in some of them they are considered to be non-profit while in some others, they are for profit. For instance in California, Colorado, lowa, Montana, Oregon, South Dakota, Wisconsin and in New York they are for profit. However, for instance, in New York their primary purpose is to provide services and means for members, which means that as a secondary purpose they can make profits. In other States Statutes cooperatives are considered to have a non-profit nature.

In most of these acts a perpetual duration is stated for the cooperatives formed under them. However, in some of them a fixed period can be stated in the articles of incorporation.

An annual renewal of the organization or the incorporation is required in some of them, as is the case of Illinois and New York. In the case of Ohio it is five years while in most of them this requisite is not stated.

As for the report required it can either be annual, as in the case of California (when there are at least 25 members in a fiscal year)and in all cases in Colorado, Georgia, Illinois, Montana, New York, Oregon, South Dakota, Virginia and Wisconsin or biannual as in the case of Arkansas and lowa. In Florida and Ohio no annual report is required. 
As we can see, the different Statutes of incorporation can be considered to be a step forward but they vary in each State, not really helping a certainty of the law.

\section{A proposed model for unincorporated cooperatives: The Uniform Limited Cooperative Association Act}

As we have seen in the previous cooperative study for the States in which there are Statutes of incorporation that can be used by worker cooperatives, in all of them these statutes create a corporate form that is owned and controlled by its members operating for their benefit. Statutes vary in their specificity and in most of them General Corporate law is applicable.

However, on August 2, 2007, the National Conference of Commissioners on Uniform State Laws adopted a model of Act in order to provide for a pattern for uniformity among the States desiring to adopt similar statutes for the unincorporated form of a cooperative. The act was amended first in 2011 and again in Boston the 12 of July 2013. This last amendment is the one that is going to be commented in the following lines.

This act was born as a modern alternative for the Uniform Agricultural Cooperative Association Act. In fact, its original working title was "Uniform Agricultural and Agricultural Related Cooperatives Act". However, it was changed during the drafting process by "Uniform Cooperative Association Act" so as to open it and not to restrict its application to agricultural associations. The final title reflects the NCCUSL recommendation that the act "is a free-standing act separate and apart from current cooperative acts and, therefore, is not a statutory replacement of other law". Thus, in the end the model act contemplates the formation of various types of limited cooperative associations, including marketing, advertising, bargaining, processing, purchasing, real estate, and worker owned cooperatives.

It is obviously only draft law that can be used by the States in order to have a common model as a different way of creating cooperatives, following that model. The idea is excellent, as if it were well conceived, based on the cooperative principles, we could have a proper model to follow and that would greatly contribute to the certainty and the expansion of cooperatives. It would definitely be a very big step towards the introduction not only of a certain uniformization but above all, certainty on what being a cooperative means. This would give this entity the understanding and awareness it deserves, thus, providing the US 
with a very good instrument to create quality and stable jobs, equality, sustainability, resiliency, etc.

Notwithstanding, as we will see, it is not going to be the case, due to the fact that the proposed Act does not necessarily base itself in the cooperative principles, even though repeatedly stating to do so.

The Model Act was adopted unanimously and signed by Commissioners by the 50 States. However, until now, it has only been enacted by Utah, Kentucky, Nebraska, DC, Colorado as Bill 11 and in this case, with many modifications from the original and Oklahoma. It can also be found in Vermont, also with changes and by the name of Mutual Benefit Enterprise ${ }^{26}$. However, the main problem can be that nothing prevents an entity from another State from incorporating itself in any of these States that have enacted the law and call themselves a cooperative, even though in essence, as we will see, in their substance, they do not need to be.

This Act is not designed to replace any of the existing state co-op laws we have seen in the previous point. Rather, it is conceived as another possible legal instrument to be adopted if the States want to do so. Thus, some provisions of the Act differ markedly from the more corporate-like framework of existing traditional cooperative statutes that have been studied before.

Thus, it can be considered to be a model Statute proposed for adoption in the individual States as an alternative to other cooperative unincorporated structures already available under State law. It is a question of choice, if the cooperative is going to have the form of a LLC, then it could choose to have this form instead, if the State enacted it.

It is a governing statute for an organization that is unincorporated but confers limited liability on its participants, like a limited liability company in effect. It permits an entity organized under it (a so called "limited cooperative association" (LCA)) to use the term "cooperative" or "coop." in its organizational name ${ }^{27}$. As we will see, this

26 Dave Gutknecht or Peter Langrock explicitly embraced the change reflected in the amendment, from Limited Cooperative Association to Mutual Benefit Enterprise, precisely because it is not wise to use the word "cooperative" for these entities.

27 Section 103 (a) (b) as permitted names includes the following:" [(a) Use of the term "cooperative" or its abbreviation, the name of a limited cooperative association must contain the phrase "limited cooperative association" or "limited cooperative" or the abbreviation "L.C.A." or "LCA". "Limited" may be abbreviated as "Ltd.". "Cooperative" may be abbreviated as "Co-op" or "Coop". "Association" may be abbreviated as "Assoc." or "Assn.". [[A limited cooperative association or a member may enforce the restrictions on the use of the term "cooperative" under this [act].] [or] [A limited cooperative association or a member may enforce the restrictions on the use of the term "cooperative" [insert cross-reference to other laws of this state].]]" 
can become a problem, as the substance of this unincorporated structure does not always coincide with the cooperative form. As we will see now, even though the writing seems to comply with cooperative principles, as general rules, in too many occasions, in the end, there are restrictions and exceptions from these general rules that end up by breaching the cooperative nature.

According to the Act's commentaries "a limited cooperative association formed under this Act is intended to provide an unincorporated cooperative structure with centralized management but democratic member control as an alternative to a limited liability company". This last has been a form of business many have turned to when the traditional cooperative form of business entity has not been receptive to outside investments. Moreover the Uniform Law Commission summary states the following: "ULCAA builds on traditional law governing cooperatives, but recognizes a growing trend toward the "New Generation Cooperative" NGC), which can combine features not readily available under traditional law, such as legally binding delivery contracts and the opportunity for outside equity investment".

I find that the main problem with this model lays exactly there as it is a great idea that could have greatly contributed to progress in this area but, conceived as it is, this outside equity investment ends up being its centerpiece and a real problem.

As PITMAN28 says: "Traditionally, a business organized on a cooperative basis subordinates the interests of the capital investor to those of the business user, or patron. Cooperative control is in the hands of its member-patrons and returns on investment capital are limited. Member-patrons are the primary source of equity capital, and net earnings are allocated on the basis of patronage instead of investment". That is the reason why I cannot agree with her about this new Act. It is not a question of opposing tradition to modernity, on the contrary is a question of sticking to the principles in order to stay true.

The main basis of the afore mentioned purpose of the proposed modern act is wrong and can be easily challenged, as it is not entirely true that the traditional system does not provide for a solution in terms of equity investment. Whenever a cooperative needs outside investment it can have different choices: the first one would be to use limited preferred stock, the second, it can use inner or outside debt and the third, they can use a separate LLC to acquire and lease to the co-

28 PITMAN, L. (2014), What is a real cooperative? Thinking about structures, principles and politics Grassroots Economic Organizing (GEO) Newsletter, http://www.geo. coop/story/whats-real-cooperative. 
op any sort of need for its project without changing the cooperatives nature. This simple solution has the advantage of keeping liabilities associated with the project clear and at another entity. Moreover, public policies can be adopted to give further solutions to this possible problem, but this act is not one of them; last, there can be many others as conversions and joint ventures.

Furthermore, when delving into the Act we can see that the main point seems to be precisely (under the cover of modernization) to open a door to outside investors. This can be worrying and a danger because it leads to losing the true cooperative meaning from its very basis (particularly for democratic ownership and democratic member control), as the new State cooperative statutes and the Act provide for an unincorporated entity to be formed with both traditional patron members and investor members ${ }^{29}$. Thus, its defining feature becomes the interposing of investors into the ownership, governance, and entitlements of a "purported cooperative". If the substance over form doctrine were to be used here, as seen in the Mississippi Valley Portland Cement v. USA case before, it would most probably fail the test ${ }^{30}$.

Therefore, in the cases where this form is adopted, the exclusion of patronage dividends may reasonably be unaccepted, as this form does not really follow the requirements we have previously seen in the tax

29 In selected ways, "investor members" are similar to limited partners in a limited partnership formed under the Uniform Limited Partnership Act (2001).

30 Remember the following reasoning: "It is the opinion of this Court, after carefully scrutinizing the structure of this taxpayer and its method of doing business, that it was not doing business with its consumer patrons or assigns in the historical sense of a consumer cooperative, but that its stockholders are in no different category from that of any corporation interested in profits, no matter whether the source of that profit be from the production of cement or any other product, and that accordingly the sums paid here are not excludable from taxable income."

So, in this case, the Court decided that the taxpayers distribution of its net profits could not be categorized as patronage dividends in the sense of Section 1388(a), as added by the Revenue Act of 1962, which provides as follows:

"(a) Patronage Dividend. - For purposes of this subchapter, the term 'patronage dividend' means an amount paid to a patron by an organization to which part I of this subchapter applies -

(1) on the basis of quantity or value of business done with or for such patron.(2) under an obligation of such organization to pay such amount, which obligation existed before the organization received the amount so paid, and(3) which is determined by reference to the net earnings of the organization from business done with or for its patrons.

Such term does not include any amount paid to a patron to the extent that (A) such amount is out of earnings other than from business done with or for patrons, or $(B)$ such amount is out of earnings from business done with or for other patrons to whom no amounts are paid, or to whom smaller amounts are paid, with respect to substantially identical transactions." 
code to consider that the entity is operating "in a cooperative basis". Remember that at least, the following requirements were needed: "(a) subordination of capital as regards control of the co-op, entitlement to its pecuniary benefits, and limitations on distributions in respect of stock; (b) democratic control by its patrons on a one-member-one-vote basis; and (c) net earnings vested in its patrons and allocated to them in proportion to their patronage".

This means that real good-will patrons of a cooperative formed following this model could not be able to fulfill their rights and apply the provisions the IRC has for them.

Even though from the very beginning, the Act states that it seeks to provide an alternative which accounts for cooperative principles to a greater extent, with less room for design abuse, and with more transparency to patron members than can be engineered by using a combination of entities to find equity investment, if we carefully delve into it, we cannot reasonably agree with it. On the contrary, the possible use of this framework may lead to "cooperatives on paper" controlled by outside investors that would not reasonably pass the judicial doctrine tests.

It cannot be forgotten that, adopting the cooperative form is a question of principles and this model Act does not really base itself in them as capital investors are accorded ownership status, governance rights and economic entitlements being called "members".

Even if the definition of what a cooperative is in the US is not that clear, we can, at least, agree on a minimum from what we have seen in previous points in the Internal Revenue Code and judicial doctrine: a cooperative must be owned and democratically controlled by the users of its services, and its benefits in the form of allocations of earnings be provided to the users of its services on the basis of their patronage. The fact that this model proposes investors and their becoming a centerpiece of the entity, even if not that apparent in a first read, does not advocate for the cooperative principles.

For instance, section 103 of the Model Act when regulating the nature of the limited cooperative association states the following: "(a) A limited cooperative association organized under this [act] is an autonomous, unincorporated association of persons united to meet their mutual interests through a jointly owned enterprise primarily controlled by those persons, which permits combining:

(1) ownership, financing, and receipt of benefits by the members for whose interests the association is formed; and

(2) separate investments in the association by members who may receive returns on their investments and a share of control." 
This second point poses a problem as, even if the first one seems all right, the word "member" is defined by the act as "a person that is admitted as a patron member or investor member, or both, in a limited cooperative association. The term does not include a person that has dissociated as a member".

This subtle change of what a member is, allowing investor members together with the second paragraph of sect.103 makes us reach the following conclusion: there are investor members who are not only going to receive returns on their investments according to equity, as we will see, but also a share of control. If that is done, where is the difference with other sorts of traditional corporations like a traditional LLC?

There are several sections that, taken together, can be disturbing. For instance, the definition of "organizer" in Section 102(21) requires an organizer to be an individual and just one individual is necessary to cope with sect. 301 to organize a cooperative. Moreover, in the commentaries to section 301, it says that "it permits the organizing of a limited cooperative association without members at the time of organization". We can infer from this that members are not necessary in order to organize a cooperative and just one individual can organize it.

Furthermore, section 502 a) states that to form this sort of cooperative it only needs for one member ${ }^{31}$. All these sections come as a surprise as they not only seem to be inconsistent but above all, as the word "Co-operative" etymologically comes from Latin from the union of the prefix co- (which means union) -operari- (which means work) and the suffix -tive (relation). This is to say, the work co-operative means working in union, working in relation with others. Thus, the only possible explanation for it comes from a systematical reading together with section 501 where in order to operate, it asks for two patron members though it still accepts one, here saying that "unless the sole member is a cooperative".

A literal interpretation of the afore seen sections leads us to the conclusion that to form a cooperative there is just a need for one person, the organizer, who must be an individual whilst to operate you can only have one person if it is not an individual! However, all this can have another possible interpretation as sec.301 allows one investor to be the sole organizer, against all common sense and this may be the reason why these sections may seem unclear.

31 Section 401 a: "If a limited liability company is to have only one member upon formation, the person becomes a member as agreed by that person and the organizer of the company. That person and the organizer may be, but need not be, different persons. If different, the organizer acts on behalf of the initial member. 
Under section 302 a) 1) the organizer, who does not need to be even a member and can be an investor may adopt the bylaws and together with sec.302 a) 2)name the initial directors and sec. 303 b) they may accept members (but the concept the Model Act has of member includes investor members). This way investors alone may constitute the entirety of patron and investor members since patron members are not required to conduct any actual patronage under Sec. 102(22). Evidently, all of this goes against the principle of open doors and against the very essence of the meaning of cooperative.

All the afore-seen could be enough not to consider adopting this form. Notwithstanding, there are more cooperative principles that become compromised under this Act.

Cooperatives are a true form of democratic participation of workers where work comes first and capital is instrumental. This is the reason why I find that section 512 goes clearly against the very essence of cooperative principles in a desire to please capital investors. In this section it is said that "the organic rules may allocate voting power among patron members on the basis of one or a combination of the following:(1) one member, one vote;(2) use or patronage;(3) equity; or(4) if a patron member is a cooperative, the number of its patron members. The organic rules may provide for the allocation of patron member voting power by districts or class, or any combination thereof".

As derived from section 512 and even explained in the commentaries, the organic rules could base voting on a percentage of equity in the limited cooperative association or on each dollar of equity in the association. The equity could be paid in capital or retained allocations in the capital accounts of the members that have not been distributed, or a combination of both ${ }^{32}$.

32 Example extracted from the commentaries of sec.512:"A member has $\$ 1,000$ of paid in capital in an association that has a total of $\$ 20,000$ in paid in capital from all voting members. In addition, the member has $\$ 15,000$ of retained allocations in the member's capital account that have not been distributed. All of the members together have $\$ 100,000$ of retained allocations in their capital accounts collectively.

The organic rules of the association could provide that voting power will be based on paid in capital. The member would have $1 / 20$, or $5 \%$, of the total voting power in the association.

The organic rules could provide that voting power will be based on retained allocations. The member would have $15 / 100$, or $15 \%$, of the total voting power.

The organic rules could provide that voting power will be based on total equity in the association, a combination of paid in capital and retained allocations. The member would have a total of $\$ 16,000$ in equity $(\$ 1,000$ of paid in capital plus $\$ 15,000$ of retained allocations). Total equities of the association as a whole would be $\$ 120,000$ ( $\$ 20,000$ of paid in equity plus $\$ 100,000$ of retained allocations). The member would have $16 / 120$, or $13.3 \%$, of the total voting power. 
This Act clearly permits the organic rules to provide for more than one vote per member in a limited cooperative association. If voting power can be allocated by equity the purported cooperative is, again, no longer one in its essence.

Moreover, section $513^{33}$ leaves an open door for the organic rules to provide an allocation not based in one member, one vote, but by classes, even though at a first glimpse to the section the general rule seems to be the contrary.

Again, section 514, when proposing the voting requirements by members seems to give the majority of patron members the power. However, the same section in its third paragraph leaves an open door for the organic rules to provide for the percentage of the affirmative votes that must be cast by investor members to approve the matter. This way, investors may even have a veto power in voting. It could even be just one investor who has it.

Moreover, following with the democratic control of members, as we have seen, it constitutes one of the main pillars in order to consider that an entity is acting "on a cooperative basis", section 402 on the notice and amendment of organic rules allows in 402.a)2) a petition signed by at least 10 percent of the investor members to propose an amendment of the organic rules.

As we have seen before, even in the case of Congress and in jurisprudence there is a serious misuse of some terminology applicable to cooperatives. It seems to be the case here, the terminology seems to me unclear as Section 1004 wrongly deals with allocations of losses and profits ${ }^{34}$.

As in previous sections, what seems to be in accordance with cooperative principles at a glimpse, when delving into the matter, can end us worrying us for not being like that at all. The purported democratic allocation of earnings does not seem to me in accordance with cooperative principles. To begin with, it would seem that by pro-

33 Section 513: "If the organic rules provide for investor members, each investor member has one vote, unless the organic rules otherwise provide. The organic rules may provide for the allocation of investor member voting power by class, classes, or any combination of classes".

34 (a) The organic rules may provide for allocating profits of a limited cooperative association among members, among persons that are not members but conduct business with the association, to an unallocated account, or to any combination thereof. Unless the organic rules otherwise provide, losses of the association must be allocated in the same proportion as profits.

(b) Unless the organic rules otherwise provide, all profits and losses of a limited cooperative association must be allocated to patron members. 
viding a minimum of a $50 \%$ of allocations of profits or losses to patrons at least patrons are going to obtain that. This way we can infer that another $50 \%$ can rest in the investor hands. However, having a closer look at this section together with the following sections and interpretative rules we get to the following in 1004.c) 2: "amounts paid, due, or allocated to investor members as a stated fixed return on equity are not considered amounts allocated to investor members". Thus, we can derive that the $50 \%$ rule of minimum allocation of profits to patron members is not exactly the case, as payments to investors for fixed dividends are not considered to be allocations, so their share of dividends is not included in their $50 \%$ of allocations. This fact, together with the absence of a limit for fixed dividends make us understand that the minimum $50 \%$ allocation of profits for patrons is not really so. If investors get their fixed dividends first, with no limit, the part to be allocated to patrons has already been diminished in favor of investors and can even be null.

After reading the 287 pages of the Model Act there are no compulsory allocations to reserve funds. The only reference to it is in sec.1004 d) where it says: "Unless prohibited by the organic rules, in determining the profits for allocation under subsections (a), (b), and (c), the board of directors may first deduct and set aside a part of the profits to create or accumulate:

(1) an unallocated capital reserve; and

(2) reasonable unallocated reserves for specific purposes, including expansion and replacement of capital assets; education, training, cooperative development; creation and

distribution of information concerning principles of cooperation and community responsibility."

Therefore, the possibility of making allocations to reserves is left to the good will of the organic rules which can even forbid them, and even if not forbidden by the organic laws, it is up to the board of directors who just may decide to do so.

I know that under a US cooperative perspective there is absolutely no obligation for cooperatives to make allocations to reserves. However, if we want our cooperatives to get strong and last for future generations allocations to reserve funds become extremely important, as they help cooperatives be resilient and they considerably reduce the need to get outside help. This point should also be dealt with in a proper possible future framework. 


\section{Conclusions}

There is an urgent need for the US to have a clear regulatory framework for worker cooperatives. Up till now, the only references there are at a federal level for these entities are included in the Internal Revenue Code.

The IRC needs to be interpreted together with judicial doctrine, as it is through the cases solved by the US Supreme Tax Court that we can have an objective and binding interpretation of what "operating on a cooperative basis" is. This should be the basis for a development in this area, as only when there is a clear choice for these entities they can become promoted. For this purpose, cooperatives should be clearly identified and strict rules should apply for a minimum based on cooperative principles. If not, there will always be abuses of the cooperative form.

If not having a cooperative clear and separate choice is bad enough for the US system, having a purported Act for them that does not base itself in cooperative principles or even the little reference the tax code makes to them, can be considered to be far worse. The existing model for the Uniform Limited Cooperative Association Act cannot be considered a real option for true cooperatives as, in the end, it does not even follow the minimum established by the IRC and judicial doctrine.

However, it is a precedent, which means that a real regulatory framework is an ideal that could be easily achieved only if the model based itself in cooperative principles, providing them with certainty, understanding and public awareness.

I understand that the exclusion of patronage refunds is promoted and justified by the agent or conduit theory. However, I find that this exclusion together with the penalization of the allocation to reserves play a very negative role in the cooperative resilience in the long term.

A compulsory percentage of returns should not be distributed, but it would be advisable for it to stay in the cooperative for the cooperatives use, allocated to reserves. In other countries in Europe these can only be obtained capitalized when the worker owner retires and in some cases, as the Spanish and Basque cases, where cooperatives become the pillar of the system, some of them not even then. Specific provisions in order to guarantee reserves, could become important in the US system if we want cooperatives not to be mules and last, as reserves make the cooperative stronger, providing it with liquidity and strength towards lenders. 
Thus, a compulsory allocation to reserves, as a percentage of the net margin, should be promoted probably by the IRC, in a way that earnings allocated to reserves become, either partly or totally excludable from the taxable base. Only if the allocation of earnings to reserves is promoted and its distribution penalized (just the opposite as the system is) will the cooperatives have enough resources to grow and be resilient in times of crisis.

If reserves are enhanced, there would be no need to look for capital investors, solving this way the problem there is in the very dangerous Uniform Limited Corporation Act who looks for outside investors losing in the way the cooperative nature.

\section{References}

ALPEROVITZ, G. 2017. Principles of a pluralistic Commonwealth, The Democracy Collaborative, Washington D.C.

BIRCHALL, J. 2005. "Co-operative principles ten years on ICA", ICA: review of international cooperation, vol 98, n 2 .

BIRCHALL, J. 2010. People-centred businesses: Co-operatives, Mutuals and the idea of Membership, Palgrave Macmillan.

GEU, T.E. and DEAN, J.B. 2009. "The new Uniform Limited Cooperative Association Act: A capital idea for principled self-help value added firms, community-based economic development, and Low- profit joint ventures", Real Property, Trust and Estate Law Journal.

GUTNECHT, Dave. 2014. "More on New Co-op laws", Endcap. Articles.

INGALSAVE, Gene and GROVES, Frank. 1989. Historical Development, in Cooperatives in agriculture.

KRUSE, D., FREEMAN, R. and BLASI, J. 2010. Shared capitalism at Work: Employee ownership, profit and gain sharing, and broad-based stock options, Chicago, Univ. of Chicago Press.

KURTULUS, F. A. and KRUSE, D., L. 2017. How Did Employee Ownership Firms Weather the Last Two Recessions?: Employee Ownership Stability and Firm Survival:1999-2011.

PAVLOSKAYA, M. 2016. Community Economies Research Collective in the United States, PSC CUNY, New York.

NESS, I. 2011. Ours to master and to own: workers control from the commune to present, New York, ed.Azzelini.

SECRETARY OF STATE'S OFFICE. 2016. Kentucky Revised Statutes Annotated, Lexis Nexis, New York.

SECRETARY OF STATES'S OFFICE. 2016. Utah Corporation Law Manual, ed Lexis Nexis, New York.

PITMANN, L. 2014. "What's a "Real" Cooperative?: Thinking about Structure, Principles and Politics". Grassroots Economic Organizing Newsletter. It can be found on the internet at: http://www.geo.coop/story/whats-real-cooperative. 
USDA. 2015. Income Tax Treatment of Cooperatives, Cooperative Information Report 44, Washington D.C.

WOODIN, T. 2015. Co-operation learning and cooperative values, Routledge, New York.

ZEULI, K.A. and CROPP, R. 2004. Cooperatives: principles and practices in the $21^{\text {st }}$ century, Uw extension. Madison. 


\section{Derechos de autor}

El Boletín de la Asociación Internacional de Derecho Cooperativo es una revista de acceso abierto lo que significa que es de libre acceso en su integridad inmediatamente después de la publicación de cada número. Se permite su lectura, la búsqueda, descarga, distribución y reutilización legal en cualquier tipo de soporte sólo para fines no comerciales y según lo previsto por la ley; sin la previa autorización de la Editorial (Universidad de Deusto) o el autor, siempre que la obra original sea debidamente citada (número, año, páginas y DOI si procede) y cualquier cambio en el original esté claramente indicado.

\section{Copyright}

The International Association of Cooperative Law Journal is an Open Access journal which means that it is free for full and immediate access, reading, search, download, distribution, and lawful reuse in any medium only for non-commercial purposes, without prior permission from the Publisher or the author; provided the original work is properly cited and any changes to the original are clearly indicated. 